\title{
Reaction of 4-Hydroxycoumarin with Salicylaldehyde: Products Formed Under Various Conditions and their Antiproliferative Activity
}

\author{
SHAZIA MUZAFFAR BANDAY* ${ }^{*}$ and KHALIQUZ ZAMAN KHAN \\ ${ }^{1}$ Department of Chemistry, University of Kashmir, Hazratbal, Srinagar, \\ Jammu \& Kashmir, 190006, India \\ shazia_m@live.in
}

Received 18 December 2016 / Accepted 22 January 2017

\begin{abstract}
The reaction of 4-hydroxycoumarin with salicylaldehyde was carried out in ethanol and water-ethanol mixture $(2: 1 \mathrm{v} / \mathrm{v})$ using conventional and microwave assisted methods. The reactions were explored leading to the formation of a single product in contrast to the two products formed usually, viz. 3-(o-hydroxybenzal)-2,4-diketochroman and 3-[6-oxo(1)benzopyran (4,3-b)-(1) benzopyran-7-yl]-4-hydroxy- $2 H$-chromen-2-one. In addition to the exclusive formation of a single product, the time of reaction was reduced considerably. The products were evaluated for their antiproliferative activity and were found to exhibit good activity in comparison to the 4-hydroxycoumarin moiety.
\end{abstract}

Keywords: 4-Hydroxycoumarin, Salicylaldehyde, Antiproliferation

\section{Introduction}

4-Hydroxycoumarin reacts with aldehydes in ethanol to give the corresponding biscoumarin. In the recent years, many methods have been developed for their synthesis using a wide variety of catalysts ${ }^{1-10}$. The reaction of 4-hydroxycoumarin with salicylaldehyde does not yield the corresponding biscoumarin ${ }^{11}$. Instead a mixture of two compounds is obtained viz. 3-(o-hydroxybenzal)-2,4-diketochroman (3b) and 3-[6-oxo(1)benzopyran(4,3-b)-(1) benzopyran-7-yl]-4-hydroxy-2H-chromen-2-one (3c). The reaction has been carried out selectively in triethylbenzylammonium chloride (TEBAC) $-\mathrm{H}_{2} \mathrm{O}$, ionic liquid, or $\mathrm{KF}-\mathrm{Al}_{2} \mathrm{O}_{3^{-}}$ EtOH resulting in different products ${ }^{12}$. However, the unusual reaction of 4-hydroxycoumarin with salicylaldehyde in ethanol has not been explored much so far. We investigated the reaction further and attempted to obtain a single product only. The compounds were evaluated for their antiproliferative activity for the first time.

\section{Experimental}

The melting points were taken in open capillaries using a Perfit Melting Point apparatus and are uncorrected. The microwave oven used was a domestic, multimode SHARP R-21LC 
model $(1000 \mathrm{~W})$. The reactions in microwave oven were carried out in sealed teflon tubes at intervals of $30 \mathrm{~s}$. Infrared spectra were recorded on a Perkin Elmer-Spectrum RX-IFTIR instrument. ${ }^{1} \mathrm{H}$ NMR spectra were recorded on a Bruker Avance II $400 \mathrm{MHz}$ NMR Spectrometer using DMSO- $d_{6}$ as solvent and tetramethylsilane (TMS) as internal standard. Mass Spectra were obtained on Waters Micromass Q-Tof Micro instrument. MTT assay was performed by recording the absorbance on a Bio-Rad Laboratories Microplate Spectrophotometer. All the chemicals used were of AR grade. HeLa cancer cell line was used for the study of antiproliferative activity. The culture medium, Dulbecco's Modified Eagle Medium (DMEM), Fetal Bovine Serum (FBS), penicillin, streptomycin and MTT reagent were purchased from Sigma Aldrich.

\section{Reaction of 4-hydroxycoumarin (1) and salicylaldehyde (2) in ethanol under conventional reflux conditions}

A mixture of 4-hydroxycoumarin (1) (4 mmol) and salicylaldehyde (2) $(2 \mathrm{mmol})$ in $15 \mathrm{~mL}$ ethanol was taken in a round-bottomed flask and refluxed on a water bath for $12 \mathrm{~h}$. The progress of reaction was monitored by thin layer chromatography. After the completion of reaction, the mixture was cooled to room temperature. The product was filtered under suction, washed with ethanol and dried. The mixture was separated by column chromatography. Products $\mathbf{3 b}$ and $\mathbf{3 c}$ were isolated.

Reaction of 4-hydroxycoumarin (1) and salicylaldehyde (2) in ethanol under microwave irradiation conditions

A mixture of 4-hydroxycoumarin (1) $(4 \mathrm{mmol})$ and salicylaldehyde (2) $(2 \mathrm{mmol})$ in $3 \mathrm{~mL}$ ethanol was taken in a sealed teflon-tube and irradiated in a microwave oven for 3 minutes. The progress of the reaction was monitored by thin layer chromatography. After the completion of reaction, the mixture was cooled to room temperature. The product $\mathbf{3 b}$ was filtered under suction, washed with ethanol and dried.

Reaction of 4-hydroxycoumarin (1) and salicylaldehyde (2) in water-ethanol (2:1 $v / v)$ under conventional reflux conditions

A mixture of 4-hydroxycoumarin (1) (4 mmol) and salicylaldehyde (2) $(2 \mathrm{mmol})$ in $15 \mathrm{~mL}$ of $2: 1 \mathrm{v} / \mathrm{v}$ water-ethanol mixture was taken in a round-bottomed flask and refluxed on a water bath for $3 \mathrm{~h}$. The progress of reaction was monitored by thin layer chromatography. After the completion of reaction, the mixture was cooled to room temperature. The product 3c was filtered under suction, washed with ethanol and dried.

\section{Spectral data}

\section{3-(o-Hydroxybenzal)-2,4-diketochroman (3b)}

Yellow, needle shaped crystals; m.p. $170-172{ }^{\circ} \mathrm{C}$; IR spectrum $(\mathrm{KBr}), v\left(\mathrm{~cm}^{-1}\right): 3069(\mathrm{O}-\mathrm{H}$ stretching), $1716(\mathrm{C}=\mathrm{O}$ stretching of ketone group), $1627(\mathrm{C}=\mathrm{O}$ stretching of lactone ring of coumarin), 1592, 1566, 1489, 1443 ( $\mathrm{C}=\mathrm{C}$ stretching of aromatic ring), 748 (C-H out-ofplane bending vibrations of benzene ring); ${ }^{1} \mathrm{H}$ NMR spectrum (DMSO- $\left.d_{6}, 400 \mathrm{MHz}\right), \delta$ (ppm): 6.91-8.28 (m, 9H, Ar-H), 10.79(s, $1 \mathrm{H}, \mathrm{OH})$; MS-ESI: calculated for $\left[\mathrm{C}_{16} \mathrm{H}_{10} \mathrm{O}_{4}-\mathrm{H}\right]$ : 265.2, found: 265.0 .

3-[6-Oxo(1)benzopyran(4,3-b)-(1)benzopyran-7-yl]-4-hydroxy-2H-chromen -2-one (3c) White crystalline solid; m.p. $240-242{ }^{\circ} \mathrm{C}$; IR spectrum $(\mathrm{KBr}), v\left(\mathrm{~cm}^{-1}\right)$ : $3003(\mathrm{O}-\mathrm{H}$ stretching), 1696, 1617 ( $\mathrm{C}=\mathrm{O}$ stretching of lactone ring of coumarin), 1665, $1641(\mathrm{C}=\mathrm{C}$ stretching of 
vinyl ether), 1569, 1488, $1454(\mathrm{C}=\mathrm{C}$ stretching of aromatic ring), 1220, 1070 (C-O-C stretching of vinyl ether), 752 (C-H out-of-plane bending vibrations of benzene ring); ${ }^{1} \mathrm{H}$ NMR spectrum (DMSO- $\left.d_{6}, 400 \mathrm{MHz}\right), \delta(\mathrm{ppm}): 5.78(\mathrm{~s}, 1 \mathrm{H}, \mathrm{CH}), 7.08-8.08(\mathrm{~m}, 12 \mathrm{H}, \mathrm{Ar}-\mathrm{H})$, 11.99 (s, 1H, OH); MS-ESI: calculated for $\left[\mathrm{C}_{25} \mathrm{H}_{14} \mathrm{O}_{6}-\mathrm{H}\right]$ : 409.3, found: 408.8 .

\section{Antiproliferative activity}

The compounds $\mathbf{3 b}$ and $\mathbf{3 c}$ were evaluated for their antiproliferative effect on human cancer cell lines, HeLa in comparison to 4-hydroxycoumarin. The cells were cultured in Dulbecco's Modified Eagle Medium (DMEM) supplemented with 10\% (v/v) Fetal Bovine Serum, $50 \mu \mathrm{g} / \mathrm{mL}$ penicillin and $100 \mu \mathrm{g} / \mathrm{mL}$ streptomycin in a humidified atmosphere of $37^{\circ} \mathrm{C}$.

The cell viability was determined using the MTT, (3-(4,5-dimethylthiazol-2-yl)-2,5diphenyltetrazolium bromide) method. HeLa cells were plated in 12-well plates in cell culture medium (DMEM) and grown overnight at $37{ }^{\circ} \mathrm{C}$ in $\mathrm{CO}_{2}$ incubator. The cells were treated with various concentrations of the compounds and incubated for $24 \mathrm{~h}$. The cytotoxicity was measured by MTT assay. $100 \mu \mathrm{L}$ of MTT $(5 \mathrm{mg} / \mathrm{mL})$ was added to each well and plates were further incubated at $37{ }^{\circ} \mathrm{C}$ for $3 \mathrm{~h}$. The MTT solution was aspirated and DMSO was added to cells, followed by incubation at room temperature for 30 minutes. The absorbance was measured at a wavelength of $570 \mathrm{~nm}$ with background subtraction at 650 $\mathrm{nm}$ using a microplate spectrophotometer.

The experiments were repeated thrice and the results were presented as the percentage of cell viability, calculated using the formula given below:

$\%$ Cell Viabilty $=($ Absorbance of treated cells/ Absorbance of untreated cells $) \times 100$

A dose-response curve was plotted for each test compound and the half maximal inhibitory concentration $\left(\mathrm{IC}_{50}\right)$ values, corresponding to the concentration of compound that inhibits $50 \%$ of the cell growth were determined.

\section{Results and Discussion}

We attempted the reaction of 4-hydroxycoumarin (1) with salicylaldehyde (2) in ethanol under conventional reflux. As already reported in the literature ${ }^{11}$ and contradicting the results reported in biscoumarin synthesis earlier ${ }^{4,8}$, the reaction does not lead to the corresponding biscoumarin i.e. 3,3'-(2-hydroxybenzylidene)-bis(4-hydroxy-2H-chromen-2-one) (3a) is not formed at all. Instead a mixture of two compounds was obtained. Of these, one was the 3-( $O$ hydroxybenzal)-2,4-diketochroman (3b) which was formed in lesser amounts and appeared as yellow coloured, needle shaped crystals. This compound is, infact, an intermediate in the condensation of 4-hydroxycoumarin (1) with salicylaldehyde (2). The major product was 3[6-oxo(1)benzopyran(4,3-b)-(1)benzopyran-7-yl]-4-hydroxy-2H-chromen-2-one (3c) which is formed by the loss of water from 3,3'-(2-hydroxybenzylidene)-bis(4-hydroxy- $\mathrm{H}$ chromen-2-one) (3a). The mechanism of reaction is given in Scheme 1. When the reflux time was increased, it was found that the yield of benzopyran product $3 \mathbf{c}$ increased and that of diketochroman $\mathbf{3 b}$ decreased. But in no instance we were able to get a single product exclusively (Table 1).

For the first time, we report the reaction of 4-hydroxycoumarin (1) with salicylaldehyde (2) under microwave irradiation conditions. A modified domestic microwave oven was used and the reactions were carried out in sealed teflon tubes in a controlled manner. In this case also, the corresponding biscoumarin i.e. 3,3'-(2-hydroxybenzylidene)-bis(4-hydroxy- $\mathrm{H}$ chromen-2-one) (3a) was not formed. Instead only the 3-(o-hydroxybenzal)-2,4diketochroman (3b) was obtained as yellow coloured, needle shaped crystals. 
Table 1. \% Yield of the products $\mathbf{3 b}$ and $\mathbf{3 c}$ formed under conventional reflux conditions ${ }^{a}$

\begin{tabular}{cccc}
\hline \multirow{2}{*}{ Entry } & \multirow{2}{*}{ Time/h } & \multicolumn{2}{c}{ Yield $^{b} / \%$} \\
\cline { 3 - 4 } & & Product (3b) & Product (3c) \\
\hline 1 & 4 & 49.24 & 28.53 \\
2 & 6 & 32.89 & 39.75 \\
3 & 8 & 22.74 & 50.48 \\
4 & 10 & 19.92 & 56.34 \\
5 & 12 & 12.78 & 61.82 \\
6 & 14 & 12.21 & 62.43 \\
7 & 16 & 11.65 & 62.68 \\
\hline
\end{tabular}

${ }^{a}$ Reaction conditions: 4 mmol 4-hydroxycoumarin, 2 mmol salicylaldehyde, $15 \mathrm{~mL}$ ethanol. ${ }^{b}$ Isolated yield<smiles>CC(C)Oc1ccccc1C(=O)COc1ccccc1C(O)C1C(=O)Oc2ccccc2C1=O</smiles>

1

2<smiles>O=C1Oc2ccccc2C(=O)CC(O)C1=Cc1ccccc1O</smiles><smiles>O=c1oc2ccccc2c(O)c1C1c2ccccc2Oc2ccccc21</smiles>

\section{Scheme 1}

When the reaction was carried out using water-ethanol mixture $(2: 1 \mathrm{v} / \mathrm{v})$ as solvent, we were able to synthesize the product, 3-[6-oxo(1)benzopyran(4,3-b)-(1)benzopyran-7-yl]-4hydroxy- $2 H$-chromen-2-one $(3 \mathbf{c})$ selectively. The reaction proceeded at a much faster rate than the conventional reflux reaction in ethanol (Scheme 2). The yield of product for different reaction times is summarized in Table 2.

Further, the antiproliferative effect of the compounds $\mathbf{1}, \mathbf{3 b}$ and $\mathbf{3 c}$ was studied and the ability to inhibit the in vitro growth of human cancer cell lines (HeLa) was evaluated. The concentration that was able to cause $50 \%$ of cell growth inhibition $\left(\mathrm{IC}_{50}\right)$ was determined by interpolation from dose-response curves (Table 3). A good antiproliferative activity was observed for the compounds $\mathbf{3 b}$ and $\mathbf{3 c}$ in comparison to the starting compound, 4hydroxycoumarin. 
Table 2. Percentage yield of product $3 \mathbf{c}$ in water-ethanol mixture $(2: 1 \mathrm{v} / \mathrm{v})$ under conventional conditions ${ }^{a}$

\begin{tabular}{cc}
\hline Time/ h & Yield $^{b} / \%$ \\
\hline 3 & 86.21 \\
5 & 86.59 \\
7 & 88.78 \\
9 & 87.54 \\
11 & 87.36 \\
\hline
\end{tabular}

${ }^{a}$ Reaction conditions: 4 mmol 4-hydroxycoumarin, 2 mmol salicylaldehyde, $15 \mathrm{~mL}$ water-ethanol (2:1 $v / v) .{ }^{b}$ Isolated yield<smiles>O=C1OC2C=CC=CC2C(O)=C1C(c1ccccc1O)c1c(O)c2ccccc2oc1=O</smiles>
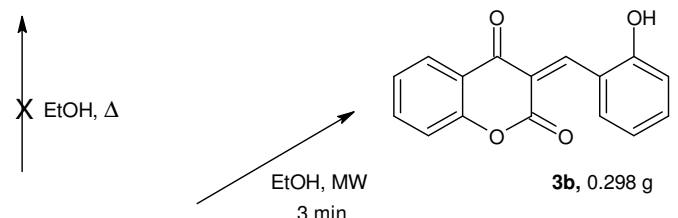

$3 b, 0.298 \mathrm{~g}$<smiles>O=Cc1ccccc1O</smiles>

$1(4 \mathrm{mmol})$
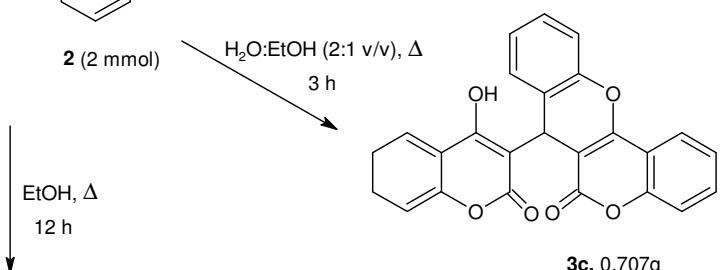

3c, $0.707 \mathrm{~g}$<smiles>O=C1Oc2ccccc2C(=O)/C1=C/c1ccccc1O</smiles>

3b, $0.068 \mathrm{~g}$<smiles></smiles>

3c, $0.507 \mathrm{~g}$

\section{Scheme 2}

Table 3. Antiproliferative effect on human cancer cell line ${ }^{a}$

\begin{tabular}{cc}
\hline Compound & $\mathrm{IC}_{50} / \mu \mathrm{M}$ \\
\hline 1 & 503 \\
$3 \mathrm{~b}$ & 226 \\
$3 \mathrm{c}$ & 159 \\
\hline
\end{tabular}

${ }^{a}$ HeLa cancer cell line 


\section{Conclusion}

We have explored the reaction of 4-hydroxycoumarin with salicylaldehyde under various conditions and achieved the formation of a single product, viz. (3-(o-hydroxybenzal)-2,4diketochroman (3b) or 3-[6-oxo(1)benzopyran(4,3-b)-(1)benzopyran-7-yl]-4-hydroxy-2Hchromen-2-one (3c) exclusively, with a considerable decrease in reaction time. The preliminary studies indicate that the synthesized compounds possess good antiproliferative activity and can be explored further.

\section{Acknowledgement}

SMB thanks Department of Science and Technology, New Delhi, India for INSPIRE fellowship.

\section{References}

1. Hagiwara H, Fujimoto N, Suzuki $\mathrm{T}$ and Ando M, Heterocycles, 2000, 53(3), 549-552; DOI: $10.3987 / C O M-99-8817$

2. Khan K M, Iqbal S, Lodhi M A, Maharvi G M, Ullah Z, Choudhary M I, Rahman A U and Perveen S, Bioorg Med Chem., 2004, 12(8), 1963-1968; DOI:10.1016/j.bmc.2004.01.010

3. Cravotto G, Nano G M, Palmisano G and Tagliapietra S, Synthesis, 2003, 1286-1291; DOI:10.1055/s-2003-39408

4. Kidwai M, Bansal V, Mothsra P, Saxena S, Somvanshi R K, Dey S and Singh T P, J Molecular Catal A: Chem., 2007, 268(1-2), 76-81; DOI:10.1016/j.molcata.2006.11.054

5. Khurana J M and Kumar S, Tetrahedron Letters, 2009, 50(28), 4125-4127; DOI:10.1016/j.tetlet.2009.04.125

6. Shaterian H R and Honarmand M, Chin J Chem., 2009, 27, 1795-1800.

7. Mehrabi H and Abusaidi H, J Iran Chem. Soc., 2010, 7(4), 890-894; DOI:10.1007/BF03246084

8. Siddiqui Z N and Farooq F, Catal Sci Technol., 2011, 1, 810-816; DOI:10.1039/C1CY00110H

9. Li W, Wang Y, Wang Z, Dai L and Wang Y, Catal Lett., 2011, 141(11), 1651-1658; DOI:10.1007/s10562-011-0689-9

10. Khurana J M and Vij K, J Chem Sci., 2012, 124, 907-912; DOI:10.1007/s12039-0120275-8

11. Sullivan W R, Huebner C F, Stahmann M A and Link K P, J Am Chem Soc., 1943, 65(12), 2288-2291; DOI:10.1021/ja01252a008

12. Wang X S, Zhou J, Yang K and Zhang M M, Synthetic Communications, 2010, 40(22), 3332-3345; DOI:10.1080/00397910903419837 